\title{
Human Rights and Duties to Alleviate Environmental Injustice: The Domestic Case
}

\author{
KRISTIN SHRADER-FRECHETTE
}

\begin{abstract}
To the degree that citizens have participated in, or derived benefits from, social institutions that have helped cause serious, life-threatening, or rights-threatening environmental injustice (EIJ), this article argues that they have duties either to stop their participation in these institutions or to compensate for it by helping to reform them. (EIJ occurs whenever children, poor people, minorities, or other subgroups bear disproportionate burdens of life-threatening or seriously harmful pollution.) After briefly defining "human rights," the article defends the four-premise responsibility argument. The argument is that people have duties to compensate for the serious, life-threatening, or rights-threatening EIJ from which they benefit, and that this compensation ideally ought to take the form of helping to reform social institutions that help cause EIJ. As such, this responsibility argument relies on two basic claims. One claim is that because citizens have benefited from, and therefore contributed to, EIJ they bear ethical responsibility to help stop it. The second claim is that because citizens participate in nations and institutions whose policies and practices help cause EIJ, they also have democratic responsibility to help stop it. The article closes by responding to four basic objections to this argument.
\end{abstract}

Environmental pollutants take a tragic toll. The US National Cancer Institute (NCI) attributes about 10 percent of US cancer deaths (about 60,000 annually) to industrial pollution in workplaces, public areas, and consumer products (HHS, NCI 1991). This figure also has been confirmed in 2005 US National Academy of Sciences studies (McGinnis 2005). Claiming this NCI figure is too low, some environmental scientists say these same industrial pollutants cause up to 33 percent of all US cancers (Ehrlich and Ehrlich 1996:154). One US Health, Education, and Welfare report says that 38 percent of all cancers are caused by only 5 high-volume industrial carcinogens (Bridbord et al. 1978). Even if the lowest of these estimates is correct, it points to public-health problems and ethics problems. A major public-health problem is that roughly 60,000 annual US cancer deaths appear to be caused by industrial pollutants, although these deaths are "theoretically preventable" (Lashof et al. 1981:3, 6).

Kristin Shrader-Frechette, author of 15 books and about 350 scholarly articles, holds appointments in both philosophy and biological sciences at Notre Dame. She writes on normative ethics, philosophy of science, and ethical and methodological issues in environmental science and risk assessment. Her articles have appeared in journals such as BioScience, Science, and Quarterly Review of Biology and also in journals such as Ethics, Human Rights Review, Journal of Philosophy, Philosophy of Science, and Public Affairs Quarterly. This article is based on a chapter from her latest book, Taking Action, Saving Lives: Our Duties to Protect Environmental and Public Health (Oxford University, 2007). Website: www.nd.edu/ kshrader

Address correspondence to Kristin Shrader-Frechette, Department of Philosophy and Department of Biological Sciences, University of Notre Dame, 100 Malloy Hall, Notre Dame, IN 46556, USA. E-mail: kshrader@nd.edu 
A key ethical problem is that these pollutant-induced fatalities are not borne equitably among the population. Children, minorities, poor people, and blue-collar workers bear the brunt of them. Consider a 2002 New England Journal of Medicine study, a multi-year analysis of childhood cancer among 90,000 twins. Designed to distinguish environmentally induced cancers from those caused by genetics, infections, or viruses, the study concluded that the environment (industrial toxins but also factors like cigarette smoke) was "overwhelmingly" implicated in causing virtually all of these childhood cancers (Lichtenstein et al. 2002). Although many adults have defenses against premature disease and death caused by air, water, and other pollution, children do not. Their developing organ systems, incomplete metabolic processes, and only partially developed detoxification systems are less able to withstand most toxins; yet per unit of body mass, children take in more air, water, and food (and thus more pollutants) than do adults (UNICEF 2005). Also, because many pollution regulations focus on cancer and only on adults, they ignore pollution-induced developmental and neurological disorders in children. US National Academy of Sciences studies show that "exposure to neurotoxic compounds [like pesticides] at levels believed to be safe for adults can result in permanent loss of brain function if it occurs during the prenatal and early childhood period of brain development" (NRC 1993:61). In general, children are at least 10 times more sensitive to any pollutant than are adults, yet for some pollutants, like organophosphate pesticides, a lethal dose in immature animals can be only 1 percent of the lethal dose for adults (Spyker and Avery 1977). The American Public Health Association (APHA) warns that because "children are often more susceptible to environmental contaminants than adults," and because government "policies and decisions" often fail to reflect this "unique susceptibility," children have "particular need for special protection from pollutants" (APHA 2000: polia, 200011).

Apart from effects of other air, water, and food pollutants, Lancet authors say that particulate air pollution alone annually causes 6.4 percent of children's deaths, ages $0-4$, in developed nations; in Europe, this means that air particulates, alone, kill 14,000 toddlers each year (Valent et al. 2004). The WHO says air pollution alone is associated with up to half of all childhood cancers (WHO 2005:155). As a consequence of children's greater sensitivity to pollutants, their annual cancer rate is increasing 1.4 percent per year, while for adults, the annual increase is 1 percent (Devesa et al. 1995; Ries et al. 1998; Epstein 2002). With their 40-percent-higher cancer increase, children are thus "the canaries in the coal mines" of industrial emissions. Minorities, poor people, and blue-collar workers also bear greater pollution, and therefore greater negative health consequences, than others do. As the APHA warns, industrial and agricultural toxins threaten millions of Americans, but occupational exposures alone kill 100,000 US blue-collar workers annually (APHA 1987, 1984). The APHA likewise says that minorities and poor people are much more likely, than other people, to receive higher exposures to pollutants like synthetic chemicals (APHA 2005). Proportionately more landfills, power plants, toxic-waste dumps, bus and rail yards, sewage plants, and industrial facilities are sited in the neighborhoods of poor people and minorities; as a result, they bear higher levels of infectious disease, contaminated air, and contaminated tap water (Shrader-Frechette 2002a; Bryant 1995; Bullard 1994). In other words, says the APHA (2005), "exposure to environmental risks varies based on race and ... income." As a result, black males' cancer incidence is 50 percent higher than for white males, and black females' cancer incidence is 30 percent higher than for white females (APHA 2005; IOM 1999; Shrader-Frechette 2007). Even after one controls for other variables-like crime, medical coverage, and income - this racial inequality is only reduced, not eliminated (IOM 2002, 1999). Such data suggest that universal health insurance, alone, will not equally protect US children, minorities, and poor people from disproportionate cancer incidence. If 
not, the solution is not to eliminate all toxic dumps or hazardous facilities but to minimize and equalize their burdens.

One of many reasons for health disparities among minorities and poor people is that the percentage of US minorities, living in counties with commercial hazardous-waste facilities, is three times higher than the percentage living in counties without them (Goldman and Fitton 1994). As the American Public Health Association has repeatedly noted, racism and environmental injustice (disproportionate pollution) must be confronted as factors in why US minorities and poor people continue to bear higher health risks; lack of health insurance cannot alone explain their higher incidence of disease and injury (APHA 2005).

\section{Overview}

How should citizens respond to these disproportionate societal harms borne by the most vulnerable members of the nation? After briefly defining "human rights," the article defends the four-premise responsibility argument. The argument is that, to the degree that citizens have participated in, or unfairly benefitted from, social institutions that have helped cause life-threatening or rights-threatening environmental injustice (EIJ), this article argues that they have prima facie duties either to stop their participation in these institutions or to compensate for it by helping to reform them. (EIJ occurs whenever children, poor people, minorities, workers, or other individuals bear disproportionate and uncompensated burdens of life-threatening or seriously harmful pollution. Prima facie duties are those that one has, in the absence of specific arguments to the contrary.) As such, this responsibility argument relies on two basic claims about different types of responsibility. One claim is that because citizens have unfairly benefited from and therefore contributed to EIJ, they bear ethical responsibility for helping to stop it. The second claim is that because citizens participate in nations and institutions whose policies and practices help cause EIJ, they also have democratic responsibility to help stop it. The article closes by responding to four basic objections to this argument.

Both types of responsibility, ethical and democratic, build on the work of distinguished scholars like Princeton University philosopher Peter Singer (2002) and New York University philosopher Peter Unger (1996). They already have given superb consequentialist arguments (based on consequences, as opposed to rights and duties) for ending world hunger. The strategy here, however, is slightly different. Using insights similar to those of Columbia University philosopher Thomas Pogge (2002), this argument builds on the heavily and almost uniquely American emphasis on human rights, especially rights to life-which prohibit threats to life and to bodily security In part this argument provides the justification for many recommendations of the American Public Health Association-including the recommendation for a US constitutional amendment that guarantees all Americans rights not to be harmed by pollutants (APHA 1998). Although this article does not provide the legal and political arguments required to implement such recommendations, it offers an initial ethical foundation for doing so.

\section{Human Rights}

As traditionally understood, human rights are a special class of moral protections with which compliance is mandatory, not discretionary. As philosopher Ronald Dworkin (1977) puts it, human rights are "trumps." They are universal claims in the sense that all humans have them, simply by virtue of being human, independent of whether particular governments recognize or implement them. Prohibitions against taking life or discrimination, human rights include 
protection of life and health, as in rights not to be tortured; protection of due process, as in rights to a fair trial; protection of political participation, as in rights to vote and to know; and, protection of equal treatment, as in rights not to be discriminated against on grounds of race or gender. As such, human rights are negative protections. They represent minimal standards for treatment of humans that governments, societies, and individuals ought to respect. They also represent standards for social criticism and reform, since oppressed minorities can appeal to human rights, and civil disobedience is often justified as a way to stop threats to them (Shrader-Frechette 2007).

Although legal rights exist only because government has recognized them, as already noted, human rights exist prior to and independent of their legal recognition. If human rights did not exist independently, there would be no standard from which to criticize the atrocities of governments who do not recognize them. How, then, does one justify the existence of human rights?

Most moral philosophers, like Ronald Dworkin (1977), argue that the characteristic, by virtue of which humans have prima facie human rights, is procedural, not factual. They believe human rights are procedural in the sense that they depend on recognizing the fundamental moral requirement of consistent and equal processes. According to this moral requirement, humans have rights not because they are rational or can exercise agency, but simply because they are human and all humans ought to be treated consistently or equally. Their claims for equal treatment are deserving of equal respect, equal consideration of their interests. As a result, they have equal human rights. Another way of formulating this procedural justification for human rights is to say that all humans (regardless of their factual characteristics) are equal subjects of "moral value." Although they may differ in intelligence or physical strength, they are equally deserving of respect or consideration precisely because they are human. As a result, they have equal rights - that is, equal claims to have their basic interests or needs considered. Espousing this procedural position, most moral philosophers have two reasons for not basing human rights on some factual characteristic, like capacity for free choice. One reason is that many humans, like infants and comatose patients, seem to retain their rights but may not always possess this characteristic. Second, such a characteristic would not enable different people to resolve their conflicting rights claims in a reasonable way. Why not? No two people possess any factual characteristic in exactly the same way or can be treated in precisely the same way. Despite some shared factual characteristic, often there are legitimate moral grounds for discriminating against some people in some respect. That is, because different people merit/need/deserve different treatment, their rights may take precedence over the rights of others. Consequently many thinkers believe that such moral justifications (rather than merely justifications based on some shared factual characteristic) seem more reasonable ways to resolve rights conflicts. Besides, regardless of their factual differences, all people deserve just procedures and equal consideration of their interests - even if they do not always deserve the same treatment. But if they deserve this equal consideration, then they have a claim to it, and if they have a claim to it, they have equal human rights (Dworkin 1977).

The problem, of course, is how to ensure genuinely equal consideration of everyone, despite different people's conflicting rights claims. Most moral philosophers use one of at least three main strategies to handle rights conflicts and to try to ensure that everyone receives equal consideration. First, they build exceptions into human rights, so that virtually none is absolute. They might say, for instance, that if a patient tells his psychiatrist that he is going to shoot someone, the killer's rights to privacy end where another person's rights to bodily security begin. Second, sometimes ethicists distinguish different classes of rights, according to which some take precedence over others. Thus Dworkin (1977) distinguishes 
strong rights, like rights to life, from weak ones, like rights to property. Strong rights are strong precisely because they are essential to personhood and human autonomy. As a result, they ought never be overridden merely to serve community welfare. Weak rights are weak precisely because, while they benefit the holder, they are not essential to personhood or autonomy. As a consequence, weak rights may be overridden whenever community welfare requires it. Other ethicists provide ways of resolving rights-conflicts by distinguishing the class of negative rights (not to be harmed, as through torture) from that of positive rights (to be benefitted, as through health care), then arguing that negative rights take primacy over positive ones. Third, moral philosophers often avoid rights conflicts by distinguishing prima facie from ultima facie rights. As already noted, prima-facie rights are those that all humans possess, in the absence of any specific arguments to the contrary. They essentially guarantee that anyone who challenges some rights-claim bears the burden of proof. Ultimafacie rights are those that rights-holders possess in the actual situation, once all relevant factual and moral details are considered. Because basic moral arguments must be applicable to a wide variety of situations, by definition they do not take into account case-specific or conflict-specific factual and moral considerations. As a result, virtually all human-rights arguments are for particular prima-facie human rights (Shue 1980; Gewirth 1982; Lyons 1979; Nickel 1987; Shrader-Frechette 2002b; Shrader-Frechette 2001).

As thus understood, human rights do not protect against all abuses. They do not protect against any inequity in people's ability to secure their needs and interests. Rather, they prohibit any person or group of people from seriously threatening someone's basic interests, like life, consent to risk, and equal treatment. Rights also protect against serious threats to human welfare and agency that arise when social systems or individuals show "official disrespect" for members' basic needs and interests. Governments often are the primary guardians of human rights, simply because they police other institutions and people. Ultimately, however, the people themselves are the final guardians of human rights. Why? At least in democratic societies, by definition, the people should control and reform the governments and social institutions on which they depend. Human rights are thus fulfilled by the many people who have causal influence over their recognition. "All humans in a position to [causally] effect" those rights must recognize them (Pogge 2002). What is recognized and fulfilled? People's basic needs and interests. Following the strong/weak characterization given earlier, the most basic or strong human right is the right to life-which prohibits threats to life or to bodily security. Close behind in importance are strong human rights to know and to consent to whatever could threaten life. These two human rights are the most basic, after rights to life, because they protect human agency, the main way people protect their lives. As thus sketched, human rights are recognized by most countries, many international treaties, and the United Nations. The Nuremberg War Trials after World War II confirmed them. Consequently, human rights are largely noncontroversial, except among some philosophical specialists. People might debate whether particular threats are genuinely human-rights threats. This article nevertheless presupposes that human rights, as such, are not controversial. Nor is it controversial that, at the peak of their powers, the Nazis disregarded human rights.

\section{The Responsibility Argument}

The basic human-rights argument here, against life-threatening EIJ, is not directed at condemning every assault suffered by every person. Rather the argument is that some "official" assaults seriously threaten people's personal security because their harm exceeds certain thresholds. Pollution that never causes anything worse than a simple cough, for instance, 
obviously does not exceed this threshold for a human-rights violation. What does exceed it? Pollution harms that cause statistically significant increases in deaths or serious injuriesespecially harms that are inequitably distributed —rise to the level of human-rights violations because of their severity and their inequitable imposition. Obviously, however, the thresholds for human-rights violations are different, depending on the different rights, people, situations, and circumstances involved. Human-rights threats of greater severity, probability, and immediacy have more stringent, more protective thresholds than threats whose severity, probability, and immediacy is lower. Likewise, the threshold for protecting children's rights to life is far more stringent than that for protecting rights of others. Children deserve more protection because they are less able to protect themselves. Using such agreedupon moral principles (that are far too numerous to be listed here), as well as the techniques of deliberative democracy, people must carefully evaluate the case-specific threshold for human-rights violations (Dworkin 1977; Pogge 2002; Shrader-Frechette 2007).

One class of human-rights violations occurs when people participate in, or unfairly benefit from, social institutions that promote or allow life-threatening EIJ. As a consequence, these people bear partial responsibility for EIJ and thus should work to stop it. This argument can be formulated in four main premises.

1. If some institutional order, like government, displays radical inequality in the degree to which citizens' human rights are fulfilled, this order is prima facie unjust (PFU), and consequently the burden of proof is on its defenders.

2. If citizens (to varying degrees) regulate this PFU order, elect its leaders, and cooperate socio-economically in it, citizens are partly responsible for this prima facie injustice.

3. If 1 and 2 are true, citizens must either defend this PFU order, withdraw from it, or compensate for the unfair benefits they gain from participation in it.

4. If withdrawal from this unjust order is unrealistic, citizens must either defend it or compensate for their unfair benefits gained from it. To defend this order, one of at least three "excusing" claims must be true:

4.1. The radically unequal human-rights condition came about through no injustice, but solely through some natural occurrence.

4.2. Victims of this radical inequality (e.g., EIJ) receive adequate compensation for threats to their human rights to life, to know, and to consent.

4.3. Alternatives to these radically unequal human-rights conditions would either fail to improve the situation or cannot be achieved, i.e., are unworkable alternatives.

5. If 3 and 4 are true, and 4.1-4.3 are false, the PFU order cannot be defended. To compensate for their benefits from it, citizens should work to stop injustice in this order.

How might one argue for each of the preceding premises and apply them to cases of EIJ (Pogge 2002; Rawls 1971)? Subsequent sections defend and apply each of these premises.

\section{The First Premise: Pollution Threats to Human Rights}

According to the first premise, institutional orders that display radical inequality in the fulfillment of human rights are PFU, and this PF injustice places the burden of proof on the order's defenders. Why do some instances of pollution cause EIJ, and therefore, radical inequality in the fulfillment of human rights? Two main factors cause some cases of EIJ to threaten human rights. These are the severity of pollution-caused harms (their high probability of leading to serious disease or death), and the inequality with which they are imposed by others. With respect to the severity, any institutional assault having a high 
probability of causing death or serious disease obviously is a threat to rights to life. But what is a high probability? If something causes an annual probability of death higher than one in a million, the US government considers this an unacceptably high probability and initiates regulation, as in the case of cancer-causing pollutants. Cancer is the leading premature killer of Americans, and as already mentioned, both US National Cancer Institute (NCI) and US National Academy of Sciences publications say at least 10 percent of all annual cancer deaths $(60,000$ of 600,000 cancer fatalities $)$ are caused by industrial and agricultural toxins (HHS and NCI 1991, McGinnis 2005; Lichtenstein et al. 2002). Other indicators of the severity of pollution threats to life are that:

- the US Office of Technology Assessment says that up to 90 percent of all cancer is "environmentally induced and theoretically preventable," where "environmentally induced" includes factors like cigarette smoke as well as industrial toxins (Lashof et al. 1981) — independent confirmation in Lichtenstein et al. (2002);

- current cancer incidence is increasing roughly 5 times faster than cancer mortality is decreasing. The average cancer victim dies 15 years prematurely (NIH 2000; Ries et al. 1998; Epstein 2002);

- the 2003 National Institutes of Health (NIH) study of 500,000 Americans in cities throughout the US showed that there is no safe level of air pollution. It annually causes between 50,000 and 100,000 US deaths (Lall et al. 2004; Pope 2003; Pope et al. 2002);

- the US Environmental Protection Agency (EPA) says that 1 in 12 (and perhaps 1 in 5) US women of childbearing age has blood levels of mercury (mainly from coal-fired plants) that can cause neurological and developmental impairment in their children (CDC 2004; OMBwatch 2006);

- a US National Academy of Sciences (NAS) study showed that one million Americans will die prematurely, over the next 75 years, from allowable pesticides on foods. Yet US pesticide use has increased by 50 percent over the last 3 decades (NRC 1996);

- the US EPA says that 45 million US citizens now drink water that does not meet the government's own safe-drinking-water standards (Cohen et al. 1996); and,

- from arsenic alone, 35 million Americans drink water that (the state of California says) will cause 1 in every 100 of them to have bladder cancer (Cohen et al. 1996; Bates et al. 1995, 1992; Chiou et al. 1995; Lai et al. 1994; Engel and Smith 1994).

The preceding illustrative statistics are alone sufficient to show that at least some avoidable US pollution threats are so severe that they constitute prima facie threats to citizens' rights to life. For the argument here to succeed, however, it is not necessary to defend a precise threshold for severity - a specific probability of death at which any pollutant threatens rights to life. Why not? Given so many instances of pollutant-induced deaths, like those noted previously, at least some serious harms obviously threaten rights to life because their probabilities are so high. Even if one of the lowest estimates for preventable, pollutant-induced cancer deaths is correct $(60,000$ annually, alleged by NCI, $\mathrm{CDC}, \mathrm{NIH}$ ), this obviously is a severe US public-health and human-rights problem. Not only have victims' rights to life been jeopardized, but they probably never fulfilled their rights to know, to give or withhold consent to, or to receive due process regarding the bodily risks others impose on them (Shrader-Frechette 2002a, 2007).

The simple point here, about determining precise thresholds for all pollution-induced human-rights threats, is often used in other ethics cases. Confronted with examples of severe racism, like Ku Klux Klan lynching, one need not be able to specify all the border cases, or all the necessary and sufficient conditions for racism, in order to know that a particular 
case of lynching was racist. Some harms are such severe instances of obvious, prima facie racism that they are noncontroversial. So also for many pollutant-induced human-rights threats. Confronted with damning health statistics like those given earlier, one need not specify a precise threshold, for all cases of pollution that threaten life and rights. For now, it is enough to know that obviously there are many cases.

Pollutants threaten human rights to life and bodily security, however, not only because of the severity of their assaults, but also because of the radical inequities that some people impose on others, as already illustrated by the health statistics, given earlier for children, minorities, and blue-collar workers. Likewise, for instance:

- the US National Academy of Sciences says cancer causes more deaths (about 6,000 annually) of US children, ages 1-15, than any other disease (IOM 2005);

- among pesticides listed as reproductive toxins by the state of California, two-thirds are still in use (Katon 1995; Olle 2000);

- half of the US pediatric asthma population lives in areas that violate EPA's ozone standards, and asthma has increased by 40 percent in the last decade (Thurston et al. 1997; CDC 1996; Friebele 1996; ALA 1995; WHO 2005); and,

- US black children aged 5 to 14 are 4 times more likely to die of asthma than are white children (APHA 2005; White et al. 1994; CDC 1996).

The preceding statistics suggest that, largely because of morally irrelevant factors (like age, race, or income level), some people's interests may receive far less consideration than others. Yet, the standard account of human rights (surveyed earlier) requires equal consideration of people's interests - procedural equality. Age, race, or income level, alone, obviously are not morally defensible grounds for treating people unequally with respect to their needs for clean air or clean water. Therefore, such seriously unequal treatment constitutes prima-facie injustice, prima-facie threats to human rights to life.

Just as with the severity of some pollution threats, the inequality displayed in the preceding instances of prima-facie environmental injustice is extreme. As a result, these inequalities are evidence of prima-facie violations of human rights. Recognizing these violations, however, requires determining no apriori threshold for inequality. Why not? At least some of the preceding inequalities are so serious and so obvious that they clearly violate human rights. Likewise, if about 1400 US children annually die from murder (DOJ 2006), and roughly another 1100 die from child abuse (Tennyson 2006), people should be even more alarmed that 6000 children annually die of cancer, most of which is preventable and environmentally induced. After such severe and inequitable harms are addressed, there will be time to debate secondary issues, like the precise thresholds for calling any harm a "human-rights violation." For now, enough evidence exists to show that, prima facie, at least some pollution is severe enough and unequal enough to threaten human rights to life.

\section{The Second Premise: Citizen Responsibility for Pollution and EIJ}

Polluters alone, however, are not responsible for pollution-related threats to life and human rights. In a complex and interdependent society, this responsibility for human-rights problems like EIJ is shared, but different for different people in different situations. Polluters typically are most responsible because they directly cause many citizens' unequal access to clean air, clean water, and equal protection of life. Insofar as special interests fail to follow the law, ignore obvious risks, or suppress health-related information, for instance, they contribute to citizens' failures to fulfill their equal human rights to life, to know, and to 
give or withhold consent to pollution-related risks. To the degree that government officials do not stop these threats, they are next most responsible. Yet, to the degree that citizens in a democracy are able to influence government, they too are responsible for these threats. As philosopher Thomas Pogge (2002) puts it, discussing global hunger, many harms are caused by "economic arrangements designed and imposed by our governments." Because "these governments are elected by us, responsible to our interests and preferences, [and] acting in our name in ways that benefit us," the "buck stops with us" (Pogge 2002). See also Feinberg (1970), Glover (1970), and Zimmerman (1988). Citizens thus bear partial ethical responsibility for pollution-induced health and human-rights threats because of the disproportionate benefits they derive from such pollution arrangements, benefits that contribute to the threats. They also bear democratic responsibility for them because of who they elect and how they participate in democratic self government. If citizens did not bear democratic responsibility, it would make no sense to hold those in a democratic society more responsible than those in a totalitarian society. Because people do hold citizens in a democracy more responsible, citizens obviously have at least some accountability for injustices perpetrated by their governments and institutions.

How do pollution-related failures in ethical responsibility occur? Whenever certain neighborhoods in northwest Indiana, New Jersey, Houston, or elsewhere receive disproportionately higher pollution, it is likely because other people receive undeserved economic benefits or less pollution. These others do not bear the full costs of their own products or activities, and their money allows them to impose their own costs on others. Consider the many metal-fabrication plants in the "Cancer Alley" of northwest Indiana (ShraderFrechette 2007). They produce goods whose consumer prices likely would be higher, if the manufacturers controlled more pollution. Thus the consumers of these goods receive unearned economic benefits-borne on the backs of residents of northwest Indiana. Or consider largely minority, south-side Chicago. It has filthy air partly because it has a disproportionate number of waste incinerators. Wealthier regions "truck out" their garbage, to be burned in the neighborhoods of the poor. To the degree that wealthy garbage-creators do not bear the full risks and costs of their own waste, they receive unearned and disproportionate economic benefits from what they unfairly impose on the poor. Although the wealthy may neither know nor intend this transfer of burdens, they have duties to inform themselves and are at least partly causally responsible for it (Pellow 2002; Shrader-Frechette 2007: 113-181; 2002a).

Often people become causally and ethically responsible for health and human-rights threats because of where they shop and what they buy. Many people shop at Wal-Mart because it has lower prices. But critics charge that Wal-Mart has lower prices because it often pays and treats its own US workers unfairly and because it buys most of its goods (from places like China), where these goods are produced under environmentally unhealthy circumstances (Lichtenstein 2006; Halbfinger 2005; Norman 2004; Bianco et al. 2003). If critics are right, and if citizens either fail to try to inform themselves of these possible misdeeds, or know about them but continue shopping at Wal-Mart without doing anything to help reform it, they are prima facie partly responsible for any harm done by Wal-Mart. Why? People have obvious negative duties not to uphold injustice. They have duties not to contribute to, profit from, or participate in, the unjust treatment of others. This is not to say, of course, that harm-causing institutions like Wal-Mart do no good. Virtually all organizations that contribute to life-threatening and rights-threatening EIJ also do great good. They may provide jobs to workers and cheaper goods to consumers. Yet, such benefits do not completely excuse unjust behavior. A person would not be excused for committing murder, merely because she also did much good in her life. Likewise, an institution is 
not fully exonerated from life-threatening EIJ, merely because it also generates significant benefits (Rosen 2002; Yesilevsky 2004).

Sweatshops are another example of why citizens have partial ethical responsibility for EIJ. In developing nations, sweatshops sometimes may provide the best work available. In the US, however, such excuses do not work because sweatshops are illegal. In the US, sweatshops are defined as providing wages violating the federal minimum, and working conditions violating the US Fair Labor Standards Act. US sweatshops typically rely on child, slave, or immigrant labor, and non-enforcement of labor laws. Numerous studies have shown that, beginning in the early 1980s, sweatshops returned to the United States. Because some US sweatshop laws are not enforced, female immigrants often work on apparel behind barbed wire, inside locked rooms, without legally required health and safety protections. They often work for $\$ 1.60$ an hour, for as long as 17 hours each day. Concentrated in New York, California, and Texas, these sweatshops produce merchandise destined for stores like Macy's, Filene's, and J. C. Penney's. The US Labor Department estimates that more than half the garment shops in these US areas violate US laws. Other social scientists say 75 percent of US apparel workers labor in sweatshop conditions-conditions of EIJ. Yet, partly because they fail to protect workers' health and human rights, sweatshops provide much cheaper textiles to US consumers. Currently, the average US household spends about 4 percent of its annual income on clothing, of which roughly half is thought to be produced under sweatshop conditions. Partly as a consequence of such US-sweatshop purchases, the percentage of US household income, now spent on clothing, is less than half of what it was 50 years ago. Sweatshop-produced apparel is now estimated to cost US consumers only about 58 percent of non-sweatshop-produced clothing. The preceding figures suggest that, without the EIJ of sweatshops, the average US household might have to spend about 5.5 (as opposed to 4) percent of its annual income to purchase the same clothing (Rosen 2002). The average US household thus saves about $\$ 650,1.5$ percent of its annual $\$ 43,300$ income, because of its (perhaps unintentional) participation in the oppression of apparel workers and its not paying the full costs of its clothing.

In comparing what US consumers save because of workplace EIJ in US and other sweatshops, note that the average US household gives about $\$ 0.30$ per day in government foreign aid, plus another $\$ 0.12$ per day in private donations to the global poor. This means the annual foreign-aid total (government and private) of the average US household is about \$153. Per person, this is about half of what the French and the English give, and about one-eighth of what the Norwegians give (Roodman 2005). These figures suggest that the average US household annually saves more than 4 times as much money, just by buying sweatshop-produced apparel, as it spends on all its foreign-aid contributions - and, that its charitable donations are less than those in some other nations.

Because of EIJ, US consumers also may fail to pay the true costs not only of sweatshopproduced clothing, but of many other goods. These include some food produced by migrant workers under exploitative conditions and heavy pesticide use, coal extracted where minesafety laws are not enforced, and so on. One reason US consumers are partly ethically responsible for various forms of EIJ is that they purchase and use many goods that often are produced in ethically questionable ways. That is, consumers participate in economic and trade relationships that are sometimes unethical—even though they may not intend it. A second reason for their partial democratic responsibility is that US consumers elect the leaders that have allowed threats to farmworkers, miners, garment workers, and otherslike poor people, minorities, children, and blue-collar workers who live near, or work at, dangerous toxic-waste dumps or highly polluting facilities. If government subsidies and nonenforcement of health and safety laws give US consumers cheaper prices for various 
goods, this is a third reason that they are partly responsible for the EIJ. All things being equal, if consumers gain disproportionate and unethical economic advantages because of environmental-health harms unfairly imposed on others, they bear partial ethical responsibility for these harms; they have duties to know the conditions under which their purchases are produced.

If the sweatshop-clothing example is typical, it suggests that just in economic terms, US consumers gain, from prima facie injustice because they fail to pay the full, humanrights, EIJ price of the goods they use. Almost all Americans are thus partly complicit in human-rights abuses, even if they do not intend them. Therefore, as the second premise of the responsibility argument maintains, they bear ethical responsibility for these abuses. This responsibility differs, depending on factors such as the level of harm caused, the benefits gained, whether beneficiaries intend the harm, whether they bear culpable ignorance for it, whether they try to prevent it, and so on. Each person's level of ethical responsibility needs to be assessed on the basis of many such factors, case by case, situation by situation, since there is no single algorithm for handling so many differences among people (Shrader -Frechette 2007: 113-181; Feinberg and Shafer-Landau 2004; Zimmerman 1988; Smith 1983; Glover 1970).

In the case of harms done by the government institutions of which citizens are a part, there likewise is no algorithm for determining one's level of democratic responsibility, and many factors (like those just mentioned) need to be considered, case by case. For instance, obviously citizens have more democratic responsibility, all things being equal, to the degree that (i) nation-caused harms are serious, (ii) citizens have personally and unfairly benefitted from them, (iii) citizens have the ability to change things, and (iv) citizens do nothing to help change things. Likewise, although there is no space here to discuss different levels of responsibility in detail, consider six situations in which citizens' democratic responsibility gradually decreases as one moves through the list. Citizens are most responsible when they elect leaders (or do nothing to stop leaders) who legally require harm to others, but less responsible when those leaders legally allow harm to others, less responsible when the leaders indirectly fail to prohibit or prevent harm to others when it could be prevented, less responsible when the leaders fail to enforce prohibitions against harms to others, and even less responsible when leaders fail to alleviate naturally induced harms such as hurricanes. Citizens are least responsible when their leaders fail to alleviate victiminduced harms, e.g, harms to smokers that occur only because they smoke in an area of already-high pollution (see Shrader-Frechette 2007: 113-181. Pogge 2002: 141-142).

\section{The Third Premise: Duties Based on Responsibility for Harm}

If premises 1 and 2 of the responsibility argument are correct, then (premise 3) citizens must either defend the prima-facie-unjust institutional order from which they benefit, or stop participating in it, or compensate for this injustice by working for reform. Why do citizens face this either-or situation? If some prima-facie-unjust institutional order exists (premise 1), citizens are responsible for this injustice if they either unfairly profit from it and bear culpable ignorance about the injustice, or if they elect those who help cause the injustice (premise 2). As a result, premise 3 requires them either to forgo their institutional membership (often not a realistic option); to compensate for their unethically obtained benefits; or to show that the alleged injustice is, ultima facie, just. Why? Justice requires avoiding complicity in pollution-related serious harms, and therefore justice also requires compensating for this complicity. All criminal and civil law is built on this same fundamental presupposition of compensation. Not to rectify some injustice or compensate for it would 
destroy the very concept of justice itself. The best compensation for some injustice is working to stop it - to change the social order that allows it (Aristotle 1976; Campbell 1988; Rawls 1971; Thomson 1986).

One also might work to benefit those most victimized by that injustice. Recognizing that such compensation is required, the APHA (1997) "urges affected communities and populations, patients, caregivers, and all concerned persons, to work in coalition," to make "urgent efforts, through legislation...advocacy and litigation, to stem further" threats to public health. It even goes so far as to endorse public-interest law groups, saying they have "stimulated citizen participation in environmental decision-making, have brought suits on behalf of citizens seeking to stop pollution, have prevented the marketing of harmful drugs and pesticides... and... given support and backing to the actions of regulatory agencies involved in consumer and environmental protection" (APHA 1974). In short, the APHA presupposes something like the responsibility argument and its third premise when it urges citizens to work for public health and environmental justice.

\section{The Fourth Premise: Excuses for Environmentally Unjust Institutions}

For the responsibility argument (RA) to establish someone's partial and ultima facie accountability for a specific case of EIJ in an institution in which she participates, however, one also would need to show that none of three "excusing" claims, 4.1 through 4.3 , are true. That is, one would need to show that the prima facie EIJ cannot be excused, ultima facie, on grounds that it involves no real injustice and occurred naturally (without human causation), has been compensated, or cannot be remedied. If any of these excuses holds, ultimately one bears no (or less) responsibility for alleged EIJ.

To assess each of these three excuses for alleged EIJ, one must investigate case-specific details. For now, however, consider how one might respond, in general, to objectors who might say the alleged EIJ arose naturally (without human causation) rather than through injustice, was compensated, and cannot be fixed by means of any alternatives. I call these, respectively, the nature-versus-injustice objection, the compensation objection, and the noviable-alternatives objection to the responsibility argument (Shrader-Frechette 2007).

\section{The Nature-Versus-Injustice Objection: Tax Policies}

Perhaps the most common response to some case of life-threatening and rights-threatening EIJ is that the pollution is "just business" or has occurred naturally (without human causation), not because of any injustice. This nature-versus-injustice response is correct insofar as there are some natural factors that exacerbate most pollution effects. Weather patterns like air inversions, for instance, might keep polluted air in a valley. This response is incorrect, however, insofar as none of the pollution harms, mentioned so far, arose only because of some natural occurrences. Rather, at least some of the harms have been worsened because of specific historical injustices. First, in general, EIJ typically is not wholly natural, as the APHA recognizes, because it is partly the result of information suppression, pollution coverup, environmental crime, misrepresentation of science, and so on, all of which threaten rights to know, to life, to equal treatment, and to consent to pollution risks (Shrader-Frechette 2007, 2002a). Most manufacturers and government officials probably are not guilty of "orchestrating ignorance" about pollution. Nevertheless, to the degree that people are unable to give or withhold genuine consent to pollution, their rights are violated. To the degree that many are guilty of covering up this life-threatening pollution, it is not merely a natural 
occurrence. Indeed, the same factors responsible for attempts to cover-up many threats to life and health are responsible for them in the first place.

A second bit of evidence, suggesting that at least some pollution-induced harm is not wholly natural, is that it is not evenly distributed across the US or across the world. Instead there are pockets of severe pollution, traceable to local contaminants disproportionately (and therefore unfairly) imposed on children, poor people, blue-collar workers, or minorities, often as a result of bearing others' burdens, like trucked-in garbage. The disparity of these burdens indicates that natural factors like poor genetics are not the main or sole cause of pollution-induced death and disease. In the case of minorities, as noted by the APHA (2005), EIJ in the US is partly a legacy of slavery, civil-rights violations, and racism that continue to the present day.

In the case of poor people, EIJ also is not wholly natural. Instead, as the APHA (2005) argues, it is partly the result of historically unjust US tax and regulatory policies. At least since the middle 1970s, these policies have benefitted the rich at the expense of the poorest 80 percent of the US. Although environmental injustice has occurred because pollution policies threaten people's rights to know, to consent, to life, and to equal treatment, tax policies have exacerbated these violations. Higher taxes have made poor people more vulnerable both to deadly pollution and to information-suppression about it because they have fewer socioeconomic resources, like medical care and good education, to deal with pollution-related threats. What are these tax policies? In 1949 the top-one-percent-richest people in the US held 22 percent of US wealth. In 1990, the top-one-percent held 35 percent of wealth. In 2002, the top-one-percent held just under 50 percent of US wealth. In only a half century, the holdings of the top-one-percent of US citizens doubled. Likewise, in 1970 the ratio between US CEO pay and US worker pay was roughly 33 to 1, whereas in 2001 it was roughly 465 to 1 (Phillips 2002). By the year 2000, the US

was the most unequal society in the advanced democratic world....the bottom 40 percent of Americans owned less than one percent of the nation's wealth. The bottom 60 percent ... less than 5 percent of wealth....The typical AfricanAmerican household had 54 cents of income...for every corresponding dollar in the typical white American household. Hispanics had 62 cents (Phillips 2002: 151-155; Piketty and Saez 2001).

The US Congressional Budget Office says such wealth concentration has not occurred purely naturally but has arisen partly because the rich have been taxed less (Phillips 2002). In constant dollars over the last 25 years, the 400 richest Americans increased their net worth by 500 percent, while the entire top-one-percent increased it by 150 percent. Yet the net worth of the middle 20 percent of all Americans decreased by 10 percent. Today, the US upper-middle class is effectively in a higher bracket than multi-millionaires. This is largely because of tax legislation with "special provisions"-like the 650 loopholes in the 1986 US "Tax Reform Act" and the 1990 "tax reform" overhaul. These "special provisions" put families earning $\$ 70,000$ to $\$ 170,000$ in the 33-percent tax bracket and those earning over $\$ 170,000$ in the 28-percent tax bracket. Yet in 1948, the median US family's effective tax rate was 5.3 percent, while that of the top-one-percent of families was 77 percent. By 1985 , both the median and top-one-percent rates were roughly 24 percent. Over the last half-century, the bottom 80 percent of Americans have borne a 500-percent increase in their share of federal tax burdens. This is partly because corporations and wealthy people have successfully lobbied to pay less. In 1950, corporations paid 27 percent of the federal tax burden, while workers' payroll taxes covered 7 percent. By 2000, corporations were 
paying only 10 percent of the federal tax burden, while payroll taxes covered 31 percent. Yet, in the last 20 years, US corporate profits have increased by 80 percent while hourly compensation in private industry has increased by only 2 percent (Federal Receipts 2001; Lewis and Allison 2002; Phillips 2002).

Even without illegal activities, such lobby-based and campaign-contribution-based economic and tax policies have created a tilted playing field that contributes to EIJ. US citizens have become less able to protect their environmental health, all things being equal, because after adjusting for inflation, most Americans have lost economic and therefore political ground over the last 5 decades. In constant dollars over the last half century, US workers' taxes, debts, and hours have all increased. US workers also have been laboring longer but earning less than many Western European counterparts. Using market-exchange rates, Germany, Denmark, Netherlands, Norway, Sweden, and Switzerland now pay their average manufacturing-production workers, respectively, 51, 22, 11, 28, 19, and 31 percent higher hourly compensation than does the US. Yet US workers now have longer hours than they did in 1950 and longer hours than the Europeans (Phillips 2002; Gates 2000; House 1996). Compared to Europeans, US workers likewise have weaker pension coverage, health coverage, vacation time, and maternity leaves. Yet, they have one of the highest rates of hypertension. As a consequence, virtually all social indicators show that US quality of life, for the bottom 80 percent of the population, after adjusting for inflation, has been declining at least since the 1970s. Based on measures such as wages, unemployment, health care, child poverty, dropout rates, drug use, violent crime, elderly poverty, and infant morality, the indices show that the current US quality of life is about 66 percent of what it was 25 years ago (Miringhoff 1999; Phillips 2002). Since the middle 1970s, the poverty rate has also been increasing, from about 11.5 percent in 1976 to about 12.7 percent (37 million people) in 2004 (IRP 2004). Such census data suggest that specific historical, socioeconomic policies of the government have contributed to poverty and racism, and thus to EIJ. Because this injustice has not occurred wholly naturally, citizens cannot excuse it as wholly natural. They bear some responsibility for it—for what their government has done.

\section{The Compensation Objection}

To the preceding economic and tax statistics, however, people might make at least two responses. First, as a general response, proponents of the compensation objection may claim that these tax policies and environmental injustices have improved everyone's welfare. Without these government policies, they say, everyone would be poorer (Beckerman 2002; Boerner and Lambert 1997: 73-75). Or, as a specific response, objectors may say that particular sets of circumstances have compensated victims of EIJ.

Consider first the general objection. It is true that Americans today have a far greater array of consumer goods than they did three decades ago. Nevertheless this increase in available goods and consumer gadgets hardly excuses or compensates for EIJ. Why not? Because the preceding census data show that over the last 30 years, the poverty rate in the US has increased, and the bottom 80 percent of Americans has become worse off, both in terms of economic welfare and in terms of quality-of-life indicators, the poorest people have little access to increased goods. Consequently, those who deserve the most compensation for EIJ are probably those who have received the least—because the poorest people are typically EIJ victims, yet the US has become more economically unequal. Because earlier census data show that increased economic inequality and decreased quality of life have undercut the alleged benefits of economic expansion, there is no apparent "increased welfare" to 
compensate for EIJ and for the declining economic welfare of 80 percent of Americans, and for the increased percentage and numbers of people living in poverty (Phillips 2002; Hacker 1997).

But perhaps proponents of the compensation argument believe victims of EIJ are somehow compensated non-economically? Victims do not appear to have more democratic or human-rights opportunities, especially since earlier statistics show that US quality of life is about 66 percent of what it was 25 years ago. All but the top 20 percent of wealthiest Americans are economically relatively worse off, in the early 21 st century, than they were a quarter-century ago. This increasing economic inequality has made it harder for most citizens to fulfill their human rights, equal opportunity, and democratic participation in government. The urgent, economic survival, has provided them less time for the important, democratic citizenship.

Nor can proponents of the compensation argument easily show that victims of EIJ are compensated through better health or health care. If anything, those most deserving EIJ compensation today are those least likely to have good health care, simply because the poorest people (without health care) are typically EIJ victims. Also, although the US is the richest nation in the world, the average health of its citizens is poor, relative to that in other western democracies. For instance:

- US infant mortality is higher than in 41 other countries (CDC 2005);

- of all industrialized nations, US rates of income inequality, poverty, and child poverty are the worst (Phillips 2002);

- the US premature-death rate is higher, and life expectancy is lower, than that in nearly all other industrialized nations (Phillips 2002; Wolff et al. 1992);

- women in the US are 70-percent more likely to die in childbirth than in Europe. The US CDC say US black women die in childbirth at nearly 4 times the rate of white women (CDC 1992); and,

- Harvard statistics show that mortality is strongly related to income inequality but not to median or per capita income (Kaplan et al. 1996).

The upshot? Proponents of the compensation argument err if they make excuses for EIJ, if they say quality-of-life, economic, democratic, or health-related opportunities somehow compensate victims of EIJ. In the last three decades in the US, instead, these four opportunities appear to have decreased, as EIJ has increased (Phillips 2002). Perhaps the same factors, responsible for EIJ, also are responsible for blocking its compensation and for increasing quality-of-life, economic, democratic, and health-related inequality. As Thomas Jefferson realized, whenever special interests have excessive concentrations of wealth, they can control life, information, and even democratic government.

Suppose proponents make a more specific compensation objection to the responsibility argument. Suppose they argue, as many libertarians do, that those who are subject to environmental pollution at work, or those who live in areas having dirty air or water, are compensated in many specific ways, Libertarians claim that citizens living in dirty areas choose to do so, pay less for housing and taxes, live closer to their jobs, and thus save in transportation costs (Payne 1997; Friedman 1994). Likewise, many economists routinely claim that people who work at dirty jobs choose to do so and are compensated by higher pay; they quote Adam Smith who says that "the whole of the advantages and disadvantages of the different employments of labor" continually tend toward equality because wages vary according to the hardship and threats of the occupation (Viscusi 1983: 37-38). Their claims about workers' compensation rest implicitly on the economic theory of hazard pay, or the compensating wage differential, according to which environmentally riskier jobs, all other 
things being equal, have higher pay (see Viscusi, Vernon, and Harrington 2000: 765-769; Viscusi 1992: 66-69; Graham and Shakow 1981). Are such compensation claims correct?

On the positive side, in principle compensation for EIJ makes sense. It is better to compensate innocent people for injustice than merely to impose uncompensated and disproportionate harms on them. Also, compensation often provides a practical way of getting dirty jobs done and of siting needed but polluting facilities, so-called LULUs-locally unacceptable land uses. For instance, the 1982 Wisconsin provisions for landfill negotiation specify compensation provisions that have made siting successful.

On the negative side, at least five reasons suggest that alleged housing, tax, transportation, or occupational pay benefits rarely compensate pollution victims. For one thing, pollution victims rarely consent to living or working in dirty air, in exchange for compensation. What poor person, worrying that her children were at risk, would willingly choose to live in dirty air, merely because housing prices were cheaper there? What poor person, worrying about a polluted workplace, would willingly put his life at risk, if he were free not to do so? Rather, social-scientific data show that people often live or work in dangerous places, against their wills, because they have no other options (e.g., Shrader-Frechette 2002a: 138-162; 1991: 72-74, 251; Berman 1978). While people may be partially compensated through lower housing prices or better pay, they do not agree that this compensation was either adequate or worth the health of themselves or their children. Instead, they often say they are unaware of the health threats, that the threats were not disclosed, or that they were exploited. Perhaps they "agreed" to cheap housing or dirty workplace air involuntarily, merely because they had no other options. If these are the responses of pollution victims, then they have not consented to pollution risks. Whenever they have not genuinely consented, the compensation objection fails, and their rights to informed consent may be jeopardized. Besides, if alleged compensation were genuine, other people would willingly move into dirty areas or dirty jobs, just to receive the alleged housing, pay, or tax "breaks." But people, who are not forced to do so, typically do not choose to move into dirty areas or dirty jobs. Therefore, benefits like cheaper housing or allegedly higher pay probably do not adequately compensate for environmental injustice (Shrader-Frechette 2002a: 138-162).

A third ethical problem with this more-specific compensation objection is that while higher pay, lower housing expenses, or lower tax costs theoretically might help compensate adults for their pollution burdens, children could never be compensated in this way. They are most damaged by pollution, least able to choose it, and largely innocent victims. For this objection to succeed, there can be no innocent third parties, seriously harmed by pollution, despite compensation. Yet, earlier statistics suggest there are many innocent victims of pollution, whether children who live in dirty air, children who are contaminated by their parents' dirty work clothing, or children who are disadvantaged by parental poor health from exposure to workplace hazards.

Even if pollution victims were somehow compensated, it is not obviously ethical for others to impose rights-threatening, equality-threatening, and life-threatening pollutants on them. In cases of medical ethics, experimenters are not allowed to expose people to serious known harms, in exchange for compensation, because this would amount to treating persons like commodities, to be bought and sold. Another classical, medical-ethics requirement is not to target vulnerable individuals and thus exploit them. If non-vulnerable people do not agree to participate in some experiment, medical ethicists take this as prima facie evidence that the experiment is ethically suspect, and that vulnerable people are somehow being targeted and exploited (NRC 2004; Jennings et al. 2003). Both examples suggest that, because medical-risk victims have protections against being targeted or deliberately harmed 
in exchange for money, EIJ-risk victims arguably also ought to have the same protections. Because they do not, the compensation argument is ethically suspect.

Apart from ethics, for the compensation objection to succeed, proponents must show that pollution victims actually receive housing, pay, or tax breaks because they breathe dirtier air. Yet much economic literature says the opposite. Especially among the poorest people with the least socioeconomic power, alleged compensation is limited or nonexistent. In poor neighborhoods, landlords often are able to get away with almost anything, including high rents and substandard housing. Why? Their clients are poor and thus less powerful. Typically even low-income-neighborhood grocery stores are overpriced, and their food is beyond the package-expiration dates. Typically even the risky jobs of the poor have no hazard pay. Many studies show that only college-educated, unionized, male, skilled, non-minority, or non-low-wage workers enjoy a compensating wage differential, while all others do not (e.g., Harmest and Wolfe 1990; Graham and Shakow 1981). Indeed, many economists say that for nonunionized and nonskilled workers, there is a negative compensating wage differential; they say that wages get lower as environmental-health threats increase (e.g., Moore 1995; Daniel and Sofer 1998; Dorman and Hagstrom 1998). This negative compensating wage differential likely occurs because, in many hazardous jobs, workers do not know the environmental-health threats they face, and they do not have other employment options, so they must work for whatever pay they can get. In other words, the same socioeconomic factors, responsible for EIJ, also often limit compensation for that injustice (Shrader-Frechette 2002a: 135-162). Consequently, both factual and ethical reasons suggest that the compensation objection fails.

\section{The No-Viable-Alternatives Objection}

Citizens might be absolved from their prima-facie responsibility for pollution-induced health and human-rights threats, however, if there were no alternatives to such threats. On the positive side, proponents of the no-viable-alternatives objection are partly correct. A bloody loaf of bread is better than no bread at all. Besides, people are morally obliged to do only what is possible. If it is not possible to reduce life- and rights-threatening pollution, people have no duty to try to reduce it. After all, ethicists agree that "ought implies can." Consequently, "cannot implies the absence of an ought." On the negative side, the objection errs in that it begs the question. To assume there are no alternatives to some EIJ, rather than to do a detailed empirical investigation in a specific case, merely creates a self-fulfilling prophecy. Besides, showing "no alternatives" to some deadly pollution seems unlikely, because of advancing technology and the impossibility of proving negatives. For pesticidal chemicals, for instance, alternatives exist. Many pesticides are not necessary, are used merely for cosmetic purposes, and can be replaced with economically viable, biological forms of pest control (Pimentel 1997).

Instead, those who make the no-viable-alternatives objection may be claiming that "it is too costly" to remedy pollution-induced human-rights violations. But this begs a second question. "Costly for whom?" For the victims of pollution or for those who profit from pollution? Obviously objectors are wrong if they assume that some people have rights to jeopardize others' lives and health simply because their own profits are at stake. Even when polluters bear high pollution-abatement costs, two reasons suggest these costs alone do not always outweigh pollution victims' claims to equal human rights, to equal protection from deadly pollution. The first reason is that, historically, the only ethically legitimate argument, considered sufficient for allowing some inequity to persist, is that it would lead to greater 
overall equality or fairness in the long run (Frankena 1962). This means that, at best, the no-viable-alternatives objection is incomplete. In addition to demonstrating empirically that there are no viable alternatives to some situation of EIJ, objectors also would have to show that the pollution and associated harms would lead to greater overall equality in the long run. Yet this would be something notoriously difficult to do because economic expansion, as such, does not decrease inequality (Shrader-Frechette 1991) —as the just-discussed US economic and tax history illustrates. The second reason (that high pollution-abatement costs do not outweigh claims to equal human rights) is that victims of life-threatening pollution typically are not requesting charity. They want an end to injustice from which other people have profited. Given polluters' profits and their imposition of injustice and deadly threats to life, it is not reasonable for polluters to say that because pollution-control is not cost-effective for them, therefore it need not be pursued.

\section{The No-Will-to-Reform Objection}

Perhaps those who object to the responsibility argument are making a different point. Regardless of what is technically or economically possible, perhaps they claim citizens $d o$ not have the will to accomplish significant reductions in EIJ or in life-threatening pollution. On one hand, polluters seem to be persuading some people not to reduce pollution. Yet manipulated consumer preferences may not indicate genuine consumer opinion. On the other hand, several factors suggest that people either have, or can develop, the will to reduce harmful pollution. For one thing, Europeans and Japanese often enjoy greater longevity and have better pollution-control than Americans (WHO 2004; Broadbent 1998; US EIA 2004; Shrader-Frechette 2007). Even if there is no causal connection between pollution control and longevity, European and Japanese successes suggest that Americans also could be convinced to reduce pollution. They suggest that developed countries can have a strong sense of community, corporate ethical obligation, and commitment to the norm that individual polluters ought not gain at the expense of the entire community.

Also, once people have more accurate information, they may have the will to control pollution. If most people were surprised by the public-health statistics already given, this fact alone suggests that these data have not played a role in their thinking about pollution. Perhaps such data will do so in the future. After all, there could hardly be a more powerful motivator than people's desire to avoid bodily harm to themselves and their children. Asking whether or not people have the moral will to help reduce life-threatening pollution is like asking people on a runaway train whether they want to stop it. Besides, people can be mobilized to support what is right. Moral force helped mobilize the nineteenth-century abolitionist movement, forcing the British government to suppress the slave trade. Moral force also was mobilized to end Apartheid in South Africa. It was behind the 1964 US Civil Rights Act. Similar moral force might be mobilized to reduce life- and rights-threatening pollution (Singer 1995).

Contemporary decision theorists, examining the Prisoner's Dilemma, help explain why moral force often helps mobilize people. They have shown empirically that often it is rational to be moral, that life is not a zero-sum game, and that all parties can gain when everyone cooperates. After all, failing to help those in need, failing to pay one's debts, failing to forgive, being envious, killing people with pollution, or allowing EIJ do not make people happy. They make people miserable. Plato, Aristotle, Aquinas, and others explained why. They argued that humans are inherently social and other-directed. As a consequence, they said human happiness depends on living in a social and other-directed way-caring for 
others. Zen Buddhists and other Asian thinkers also located the source of happiness in being good or virtuous, not in things like money, power or pleasure. Their insights suggest that people can be motivated to recognize the prima facie duty to reduce life-threatening EIJ because accepting this duty fulfills their essentially social, other-directed nature. As a consequence, it also will make them authentically happy. Accepting this argument also may promote one's own survival, not just that of EIJ victims. Speaking of his experiences in a Nazi concentration camp, Viennese Jewish psychologist Viktor Frankl claimed that the only inmates who were able to survive the horrific conditions were those who looked out for others, who remained idealistic, or who found meaning in something beyond themselves. Those who did not turn outward, he said, succumbed to torture, despair, infection, or injury. They eventually died. Frankl (1964) even quotes the German philosopher Nietzsche: "He who has a why to live for can bear almost any how" (Singer 1995; Shrader-Frechette 2007, 2002a).

\section{Conclusion}

This article argues that the three "excuses" fail, and thus that the responsibility argument has at least a prima facie plausibility. How should people respond to this argument? What should they do? Perhaps the first thing is to recognize the power of ordinary people, evident in the American Revolution. Commenting on the era, some historians claim that only about 17 percent of the colonial population supported breaking away from the British. The merchant and industry class did not because it was bad for business (Gromyko and Hellman 1988). The task of fighting for justice was left to others, just as it is today. What would happen today if 17 percent of people became aware of environmental-health threats and their responsibility for them? What would happen if they were convinced by the health data, inspired by ethics, and committed to do something about them? The Responsibility Argument calls for another revolution, an ethical transformation directed at full citizen participation and institutional reform, to "make democracy work." This is not a revolution recommended merely by charity, but one demanded by justice. It also is not a revolution that relies on accepting some new ethics. Instead it asks only that people rededicate themselves to the same goal that inspired our ancestors more than two centuries ago-universal human rights.

\section{References}

AMERICAN LUNG ASSOCIATION (ALA). (1995) Danger Zones. (Washington, DC: ALA.)

AMERICAN PUBLIC HEALTH ASSOCIATION (APHA). (1974) Endorsement of Public Interest Law Groups (Washington, DC: APHA.) [Online]. Available: http://www.apha.org/legislative/ policy/policysearch/index.cfm?fuseaction=view\&id=773 [15 March 2006].

AMERICAN PUBLIC HEALTH ASSOCIATION (APHA). (1984) Increasing worker and community awareness of toxic hazards in the workplace. (Washington, DC: APHA.) [Online]. Available: http://www . apha.org/legislative/policy/policysearch/index.cfm? fuseaction $=$ view\&id $=1078$ [16 March 2006].

AMERICAN PUBLIC HEALTH ASSOCIATION (APHA). (1987) Strengthening worker/ community right-to-know (Washington, DC: APHA.) [Online]. Available: http://www. apha.org/legislative/policy/ policysearch/index.cfm?fuseaction=view\&id=1143 [16 March 2006].

AMERICAN PUBLIC HEALTH ASSOCIATION (APHA). (1997) Protecting health-care accessibility and quality in a profit-oriented market (Washington, DC: APHA.) [Online]. Available: http://www.apha.org/legislative/policy/policysearch/index.cfm?fuseaction=view\&id=136 [15 March 2006]. 
AMERICAN PUBLIC HEALTH ASSOCIATION (APHA). (1998) Human rights in the curricula for health professionals. (Washington, DC: APHA). [Online]. Available: http://www.apha. org/legislative/ policy/policysearch/index.cfm?fuseaction=view\&id=165 [17 March 2005].

AMERICAN PUBLIC HEALTH ASSOCIATION (APHA). (2000) 2000 Policy Statements, The Precautionary Principle and Children's Health, policy 200011. (Washington, DC: APHA.) [Online]. Available: http://www.apha.org/legislative/policy/Pols2000_rev.pdf [18, February 2006].

AMERICAN PUBLIC HEALTH ASSOCIATION (APHA). (2005) Priority 2005 issues: Fact sheets, health disparities, environmental disparities, and racial/ethnic disparities (Washington, DC: APHA.) [Online]. Available: http://www.apha.org/legislative/legislative/index.htm [19 February 2006].

ARISTOTLE (1976) Nicomachean Ethics, transl. A. K. Thomson (Harmondsworth: Penguin).

BATES, Michael N., SMITH, Allan H., and CANTOR, Kenneth P. (1995) Case-control study of bladder cancer and arsenic in drinking water. American Journal of Epidemiology, 141(6), 523530 .

BATES, Michael N., SMITH, Allan H., and HOPENHAYN-RICH, Claudia. (1992) Arsenic ingestion and internal cancers. American Journal of Epidemiology, 135(5), 462-476.

BECKERMAN, Wilfred. (2002) The Poverty of Reason (Washington, DC: Independent Institute).

BERMAN, Daniel M. (1978) Death on the Job (London: Monthly Review Press).

BIANCO, Anthony, and ZELLNER, Wendy. (2003) Is Wal-Mart too powerful? Business Week, 3852, $100-110$.

BOERNER, Christopher, and LAMBERT, Thomas. (1997) Environmental injustice. In Taking Sides, Theodore Goldfarb (ed.) (Guilford, CT: McGraw-Hill), pp. 73-75.

BRIDBORD, Kenneth, DECOUFLE, Phillipe, FRAUMENI, Joseph F. Jr., HOEL, David G., HOOVER, Robert N., RALL, David P., SAFFIOTI, Umberto, SCHNEIDERMAN, Marvin A., UPTON, Arthur C., and DAY, Nicholas R. (1978) Estimates of the Fraction of Cancer in the United States Related to Occupational Factors (Bethesda: NCI, National Institute of Environmental Health Sciences, and National Institute for Occupational Safety and Health).

BROADBENT, Jeffrey. (1998) Environmental Politics in Japan (Cambridge: Cambridge University Press).

BRYANT, Bunyan, Ed. (1995) Environmental Justice (Washington, DC: Island Press).

BULLARD, Robert, Ed. (1994) Unequal Protection (San Francisco: Sierra Club Books).

CAMPBELL, Tom. (1988) Justice (Basingstoke, UK: Macmillan).

CENTERS FOR DISEASE CONTROL AND PREVENTION (CDC). (1992) Vital Statistics (Washington, DC: US Government Printing Office).

CENTERS FOR DISEASE CONTROL AND PREVENTION (CDC). (1996) Asthma mortality and hospitalization among children and young adults-United States, 1980-1993. Morbidity and Mortality Weekly Report, 45(17), 350-353.

CENTERS FOR DISEASE CONTROL AND PREVENTION (CDC). (2004) Blood Mercury Levels in Young Children and Childbearing-Aged Women (Washington, DC: CDC).

CENTERS FOR DISEASE CONTROL AND PREVENTION (CDC). (2005) Infant Mortality Fact Sheet. (Washington, DC: CDC.) [Online]. Available: http://www.cdc.gov/omh/AMH/factsheets/ infant.htm [21 January 2005].

CHIOU, Hung-Yi, HSUEH, Yu-Mei, LIAW, Kuen-Fu, HORNG, Shan-Far, CHIANG, Ming-Hsi, PU, Yeang-Shiau, LIN, Jonny-Shinn-Nan, HUANG, Chun-Hsiung, and CHEN, Chien-Jen. (1995) Incidence of internal cancers and ingested inorganic arsenic. Cancer Research, 55(6), 12961300.

COHEN, Brian, WILES, Richard, CAMPBELL, Chris, and OLSON, Erik D. (1996) Just Add Water: Violations of Federal Health Standards in Tap Water (Washington, DC: Environmental Working Group of the Natural Resources Defense Council).

DANIEL, Christophe, and SOFER, Catherine. (1998) Bargaining, compensating wage differentials, and dualism of the labor market. Journal of Labor Economics, 16(3), 546-576.

DEPARTMENT OF JUSTICE (DOJ). (2006) Murder. (Washington, DC: FBI). [Online]. Available: http://www.fbi.gov/ucr/cius_04/offenses_reported/violent_crime/murder.html [18 August 2006]. 
DEVESA, Susan S., BLOT, William J., STONE, B., MILLER, Barry A., TARONE, Rober E., and FRAUMENI, Joseph F. (1995) Recent cancer trends in the United States. Journal of the National Cancer Institute, 87(3), 175-182.

DORMAN, Peter, and HAGSTROM, Paul. (1998) Wage compensation for dangerous work revisited. Industrial and Labor Relations Review, 52(1), 116-136.

DWORKIN, Ronald. (1977) Taking Rights Seriously (Cambridge, MA: Harvard University Press).

EHRLICH, Paul R., and EHRLICH, Anne H. (1996) Betrayal of Science and Reason (Washington, DC: Island Press).

ENGEL, Robert R., and SMITH, Allan H. (1994) Arsenic in drinking water and mortality from vascular disease. Archives of Environmental Health, 49(5), 418-427.

EPSTEIN, Samuel. (2002) Reversing the cancer epidemic. Tikkun, 17(3), 56-66.

FEDERAL RECEIPTS AND OUTLAYS. (2001) Economic Report of the President (Washington, DC: US Government Printing Office).

FEINBERG, Joel. (1970) Doing and Deserving (Princeton, NJ: Princeton University Press).

FEINBERG, Joel, and SHAFER-LANDAU, Russ. (2004) Reason and Responsibility (Belmont, CA: Wadsworth).

FRANKENA, William. (1962) The concept of social justice. In Social Justice, Brandt, Richard B. (ed.) (Englewood Cliffs, NJ: Prentice-Hall).

FRANKL, Victor E. (1964) Man's Search for Meaning, transl. Lasch, Ilse (London: Hodder and Stoughton).

FRIEBELE, Elaine. (1996) The attack of asthma. Environmental Health Perspectives, 104(1), 22-25.

FRIEDMAN, David. (1994) The environmental racism hoax. American Enterprise, 9(6), 75.

GATES, Jeff. (2000) Democracy at Risk (New York: Perseus Books).

GEWIRTH, Alan. (1982) Human Rights (Chicago: University of Chicago Press).

GLOVER, Jonathan. (1970) Responsibility (London: Routledge).

GOLDMAN, Benjamin, and FITTON, Laura. (1994) Toxic Wastes and Race Revisited (Washington, DC: Center for Policy Alternatives).

GRAHAM, Julie, and SHAKOW, Don M. (1981) Risk and Reward. Environment, 23(8), 14-45.

GROMYKO, Anatoly, and HELLMAN, Martin, (eds.) (1988) Breakthrough (New York: Walker \& Company).

HACKER, Andrew. (1997) Money (New York: Touchstone).

HALBFINGER, David M. (2005) Taking On a Giant. New York Times, 154(53232), 6 June, E1-E7.

HARMEST, Daniel, and WOLFE, John. (1990) Compensating wage differentials. Journal of Labor Economics, 8(1), S175-S197.

HEALTH AND HUMAN SERVICES (HHS) and NATIONAL CANCER INSTITUTE (NCI) (1991) Health status objectives. Cancer, 16(1), 416-440.

HOUSE DEMOCRATIC POLICY COMMITTEE (House). (1996) Who Is Downsizing the American Dream? (Washington, DC: US Government Printing Office).

INSTITUTE FOR RESEARCH ON POVERTY (IRP). (2004) Who Was Poor in 2004? (Madison, WI: IRP) [Online]. Available: http://www.irp.wisc.edu/faqs/faq3.htm [26 October 2006].

INSTITUTE OF MEDICINE (IOM). (1999) The Unequal Burden of Cancer (Washington, DC: National Academy Press).

INSTITUTE OF MEDICINE (IOM). (2002) Unequal Treatment: Confronting Racial and Ethnic Disparities in Health Care, Brian D. Smedley, Adrienne Y. Stith, and Alan R. Nelson (eds.) (Washington, DC: The National Academy Press).

INSTITUTE OF MEDICINE (IOM). (2005) Rebuilding the Unity of Health and the Environment, L. Jones, J. Paretto, and C. Coussens (eds.) (Washington, DC: National Academy Press).

JENNINGS, Bruce, KAHN, Jeffrey, MASTROIANNI, Anna, and PARKER, Lisa S. (2003) Ethics and Public Health (Washington, DC: Association of Schools of Public Health).

KAPLAN, George A., PAMUK, Elsie R., LYNCH, J. W., COHEN, Richard D., and BALFOUR, Jennifer L. (1996) Inequality in income and mortality in the United States. British Medical Journal, 312(7037), 999-1003. 
KATON, Ann. (1995) Simplification of Adverse Effects Information for SB 950 Chemicals (Sacramento, CA: California Rural Legal Assistance Foundation).

LAI, Mei-Shwu, HSUEH, Yu-Mei, CHEN, Chen-Jen, SHYU, Mei-Pyng, CHEN, Shu-Yuan, KUO, Tsung-Li, WU, Meei-Maan, and TAI, Tong-Yuan (1994) Ingested inorganic arsenic and prevalence of diabetes melitus. American Journal of Epidemiology, 139(5), 484492.

LALL, Ramona, KENDALL, Michaela, ITO, Kazuhiko, and THURSTON, George D. (2004) Estimation of historical annuals PM2.5 exposures for health effects assessment. Atmospheric Environment, 38(31), 5217-5226.

LANDRIGAN, Philip J. (1996) The prevention of occupational cancer. CA: A Cancer Journal for Clinicians, 46(4), 254-255.

LASHOF, Joyce C., BANTA, David, GOUGH, Michael, FENSTERHEIM, Robert J., and GELBAND, Hellen. (1981) Assessment of Technologies for Determining Cancer Risks from the Environment (Washington, DC: Office of Technology Assessment).

LEWIS, Charles, and ALLISON, Bill. (2002) The Cheating of America (New York: Harper Collins Publishers, Inc.).

LICHTENSTEIN, Nelson. (2006) Wal-Mart (New York: New Press).

LICHTENSTEIN, Paul, HOLM, Niels V., VERKASALO, Pia K., ILIADOU, Anastasia, KAPRIO, Jaakko, KOSKENVUO, Markku, PUKKALA, Eero, SKYTTHEE, Axel, and HEMMINKI, Kari. (2002) Environmental and heritable factors in the causation of cancer. New England Journal of Medicine, 343(2), 78-85.

LYONS, David, ed. (1979) Rights (Belmont, CA: Wadsworth).

McGINNIS, J. Michael. (2005) Attributable risk in practice. In Estimating the Contributions of Lifestyle-Related Factors to Preventable Death, Institute of Medicine, Jonathan A. Samet, J. Michael McGinnis, and Michael A. Soto (eds.) (Washington, DC: National Academy Press), pp. 17-19.

MIRINGHOFF, Marc L. (1999) The Social Health of the Nation (New York: Oxford University Press).

MOORE, Michael J. (1995) Unions, employment risks, and market provision of employment risk differentials. Journal of Risk and Uncertainty, 10(1), 57-70.

NATIONAL INSTITUTES OF HEALTH (NIH). (2000) Cancer Rates and Risks (Washington, DC: NIH and NCI) [Online]. Available: http://seer.cancer.gov/publications/raterisk [3 February 2006].

NATIONAL RESEARCH COUNCIL (NRC). (1996) Carcinogens and Anticarcinogens in the Human Diet (Washington, DC: National Academy Press).

NATIONAL RESEARCH COUNCIL (NRC). (2004) Intentional Human Dosing Studies (Washington, DC: National Academy Press).

NATIONAL RESEARCH COUNCIL (NRC). (1993) Pesticides in the Diets of Infants and Children (Washington, DC: National Academy Press).

NICKEL, James. (1987) Making Sense of Human Rights (Berkeley, CA: University of California Press).

NORMAN, Al. (2004) The Case Against Wal-Mart (Atlantic City, NJ: Raphel Marketing)

OLLE, Teresa M. (2000) P is for Poison: Update on Pesticide Use in California Schools (Sacramento, CA: California Public Interest Research Group).

OMBwatch (2006) One in five women carries too much mercury. OMB Watch, 7(4), 9-10.[Online]. Available http://www.ombwatch.org/article/articleview/3296/1/429 [10 March 2006].

PAYNE, Henry. (1997) Environmental justice. Reason, 29(4), 53-56.

PELLOW, David N. (2002) Garbage Wars: The Struggle for Environmental Justice in Chicago (Cambridge, MA: MIT Press).

PHILLIPS, Kevin. (2002) Wealth and Democracy (New York: Broadway).

PIKETTY, Thomas, and SAEZ, Emmanuel. (2001) Income inequality in the United States, 19131998. In National Bureau of Economic Research Working Paper No. W8467 (Washington, DC: NBER). 
PIMENTEL, David. (1997) Assessment of environmental and economic impacts of pesticide use. In Technology and Values, Shrader-Frechette, Kristin, and Westra, Laura (eds.) (Savage, MD: Rowman and Littlefield).

POGGE, Thomas W. (2002) World Poverty and Human Rights (Cambridge, UK: Polity).

POPE, C. Arden. (2003) Cardiovascular mortality and long-term exposure to particulate air pollution. Circulation, 109(6), 71-77.

POPE, C. Arden, BURNETTE, Richard T., THUN, Michael J., CALLE, Eugenia E., KREWSKI, Daniel, ITO, Kazuhiko, and THURSTON, George D. (2002) Lung cancer, cardiopulmonary mortality, and long-term exposure to fine particulate air pollution. Journal of the American Medical Association, 287(9), 1132-1141.

RAWLS, John. (1971) A Theory of Justice (Cambridge, MA: Harvard University Press).

RIES, Lynn A. G., EISNER, Milton P., KOSARY, Carol L., HANKEY, Benjamin F., MILLER, Barry A., CLEGG, Limin, and EDWARDS, Brenda K. (eds.) (1998) SEER Cancer Statistics Review, 1973-1998 (Washington, DC: National Cancer Institute and National Institutes of Health).

ROODMAN, David. (2005) How Much Does the US Help? (Washington, DC: Center for Global Development). [Online]. Available: http://www.cgdev.org/content/opinion/detail/2959 [10 May 2006].

ROSEN, Ellen. (2002) Making Sweatshops (Berkeley, CA: University of California Press).

SCHULTE, Paul. (2005) Characterizing the burden of occupational injury and disease. Journal of Occupational and Environmental Medicine, 47(6), 607-622.

SHRADER-FRECHETTE, Kristin. (1991) Risk and Rationality (Berkeley, CA: University of California Press).

SHRADER-FRECHETTE, Kristin. (2001) MacIntyre on human rights. The Modern Schoolman, 79(1), 1-21.

SHRADER-FRECHETTE, Kristin. (2002a) Environmental Justice: Creating Equality, Reclaiming Democracy (New York: Oxford University Press).

SHRADER-FRECHETTE, Kristin. (2002b) Natural rights and human vulnerability: Aquinas, MacIntyre, and Rawls. Public Affairs Quarterly, 16(2), 99-124.

SHRADER-FRECHETTE, Kristin. (2007) Taking Action, Saving Lives: Our Duties to Protect Environmental and Public Health (New York: Oxford University Press).

SHUE, Henry. (1980) Basic Rights (Princeton, NJ:Princeton University Press).

SINGER, Peter. (1995) How Are We To Live? (Amherst, MA: Prometheus).

SINGER, Peter. (2002) One World (New Haven, CT: Yale University Press).

SMITH, Holly. (1983) Culpable ignorance. Philosophical Review, 92: 543-571.

SPYKER, Joan M. and AVERY, David L. (1977) Neurobehavioral effects of prenatal exposure to the organophosphate diazinon in mice. Journal of Toxicology, and Environmental Health, 5, 989-1002.

TENNYSON CENTER FOR CHILDREN. (2006) The Reality of Child Abuse. (Denver: Tennyson Center) [Online]. Available: http://www.childabuse.org/about\%20child\%20abuse.html [18 August 2006].

THOMSON, Judith Jarvis. (1986) Rights, Restitution and Risk (Cambridge, MA: Harvard University Press).

THURSTON, George D., LIPPMANN, Morton, SCOTT, Maryanne B., and FINE, Jonathan M. (1997) Summertime haze air pollution and children with asthma. American Journal of Critical Care Medicine, 155(2), 654-660.

UNGER, Peter. (1996) Living High and Letting Die (New York: Oxford University Press).

UNITED NATIONS INTERNATIONAL CHILDREN'S EMERGENCY FUND (UNICEF). (2005) State of the World's Children, 2005 (New York: UNICEF).

US DEPARTMENT OF HEALTH AND HUMAN SERVICES (HHS) AND NATIONAL CANCER INSTITUTE (NCI). (1991) Health status objectives. Cancer, 16(1), 416-440

US ENERGY INFORMATION AGENCY (US EIA). (2004) Japan: Environmental Issue (Washington, DC: US Department of Energy). 
VALENT, Francesca, LITTLE, d'Anna, BERTOLLINI, Roberto, NEMER, Leda E., BARBON, Fabio, and TAMBURLINI, Georgio. (2004) Burden of disease attributable to selected environmental factors and injury among children and adolescents in Europe. Lancet, 363(9426) 2032-2039.

VISCUSI, W. Kip. (1992) Fatal Tradeoffs (New York: Oxford University Press).

VISCUSI, W. Kip. (1983) Risk by Choice (Cambridge, MA: Harvard University Press).

VISCUSI, W. Kip, Vernon, J., and Harrington, J. (2000) Economics of Regulation and Anti-Trust (Cambridge, MA: MIT Press).

WHITE, Mary C., ETZEL, Ruth A., WILCOX, Wallace D., and LLOYD, Christine. (1994) Exacerbations of childhood asthma and ozone pollution in Atlanta. Environmental Research, 65(1), $56-68$.

WOLFF, Michael, RUTTEN, Peter, BAYERS, Albert F., and the WORLD BANK RESEARCH TEAM. (1992) Where We Stand (New York: Bantam).

WORLD HEALTH ORGANIZATION (WHO). (2004) World Health Report 2004, Statistical Annex. (Geneva: WHO) [Online]. Available http://www.who.int/whr/2004/en/ [1 July 2005].

WORLD HEALTH ORGANIZATION (WHO). (2005) Effects of Air Pollution on Children's Health (Bonn: WHO).

YESILEVSKY, Anna. (2004) The case against sweatshops. Humanist, 6(3), 20-46.

ZIMMERMAN, Michael. (1988) An Essay on Moral Responsibility (Savage, MD: Rowman and Littlefield). 
Copyright of Journal of Human Rights is the property of Routledge and its content may not be copied or emailed to multiple sites or posted to a listserv without the copyright holder's express written permission. However, users may print, download, or email articles for individual use. 